\title{
Improving Tolerance of Faba Bean during Early Growth Stages to Salinity through Micronutrients Foliar Spray
}

\author{
Mohamed M. EL FOULY' ${ }^{11}$,Zeinab M. MOBARAK ${ }^{11}$, Zeinab A. SALAMA ${ }^{2)}$ \\ 1) National Reasearch Centre (NRC), Fertilization Technology Department, Cairo-Dokki,Egypt; mohelfouly@link.net \\ ${ }^{2)}$ National Reasearch Centre (NRC), Plant Biochemistry Department, Cairo-Dokki, Egypt
}

\begin{abstract}
Salinity, either of soil or of irrigation water, causes disturbances in plant growth and nutrient balance. Previous work indicates that applying nutrients by foliar application increases tolerance to salinity. A pot experiment with three replicates was carried out in the green house of NRC, Cairo, Egypt, to study the effect of micronutrients foliar application on salt tolerance of faba bean. Two concentrations of a micronutrient compound $(0.1 \%$ and $0.15 \%)$ were sprayed in two different treatments prior to or after the salinity treatments. Levels of $\mathrm{NaCl}(0.00-1000-2000-5000 \mathrm{ppm})$ were supplied to irrigation water. Results indicated that 2000 and $5000 \mathrm{ppm} \mathrm{NaCl}$ inhibited growth and nutrient uptake. Spraying micronutrients could restore the negative effect of salinity on dry weight and nutrients uptake, when sprayed either before or after the salinity treatments. It is suggested that micronutrient foliar sprays could be used to improve plant tolerance to salinity.
\end{abstract}

Keywords: salinity, faba bean, micronutrients, iron-manganese-zinc-foliar spraying

\section{Introduction}

Soil salinity in agriculture soils refers to the presence of high concentration of soluble salts in the soil moisture of the root zone. Salinity is a major factor limiting the crop productivity in the arid and semi arid areas as a result of high evaporation and inappropriate irrigation techniques (Khan and Duke, 2001).

Egypt is present in semi arid region of the world. Thus, sea water utilization has been a recent effort to explore the possibility of obtaining reasonable yield and quality from different crops. Salinity is the most important problem of irrigated agriculture while one fifth of the irrigated land of the world is salt affected. Every year $0.2-0.4 \%$ of the total arable land is going out of cultivation because of salinity and water logging. So, it is essential that income generating agriculture system should be adopted in severely salt affected areas.

Salinity affects plant physiology through changes of water and ionic status in the cells (Hasegawe et al., 2000). Ionic imbalance occurs in the cells due to excessive accumulation of $\mathrm{Na}^{+}$and $\mathrm{Cl}^{-}$and reduces uptake of other mineral nutrients, such as $\mathrm{K}^{+}, \mathrm{Ca}^{2+}$ and $\mathrm{Mn}^{2+}$ (Lutts et al., 1999).

Salinity, either of soil or of irrigation water causes disturbances in plant growth and nutrient balance (Tester and Davenport , 2003).Salinity had adverse effects on the biomass and relative growth rate and other morphological parameters of common bean seedlings, also, photosynthesis, transpiration rate and stomatal conductance adversely affected (Gama et al., 2007)
Plants differ greatly in their tolerance of salinity, as reflected in their different growth responses. The variation of salinity tolerance in dicotyledonous species is greater than of monocotyledonous species. Most legume species are sensitive to salinity (Munns et al., 2004).

To improve crop growth and production in the saltaffected soils, the excess salts must be removed from the root zone. Methods commonly used in reclamation such soils are scraping, flushing and leaching. These methods were found to be very expensive.

Recently attention was given to use other new technologies of combating salinity, among them some using halophytes, as a new approach to minimize the harmful effect of salinity through nutrient management. One approach is the use of foliar sprays for increasing plant tolerance to salinity by alleviating $\mathrm{Na}^{+}$and $\mathrm{Cl}^{-}$injury to plants (ElFouly and Salama, 1999; El-Fouly et al., 2002; El-Fouly et al., 2004).

Previous work was conducted on wheat plant indicating that micronutrient foliar application led to increase plant tolerance to salinity (El-Fouly et al., in press). The objective of this study was to investigate the effect of micronutrient foliar sprays (mixture of, $\mathrm{Fe}, \mathrm{Mn}, \mathrm{Zn}$ ) on faba bean regarding the tolerance to $\mathrm{NaCl}$ salinity during early growth stages.

\section{Materials and methods}

The present study was conducted under greenhouse conditions at the National Research Centre. Seeds were 
sown in Mitcherlich pots filled with $7 \mathrm{Kg}$ soil. Basic fertilizers used were mixed with the soil in doses of $2.0 \mathrm{~g}$ triple phosphate $\left(37 \% \mathrm{P}_{2} \mathrm{O}_{5}\right), 2.0 \mathrm{~g}$ ammonium nitrate $(33 \% \mathrm{~N})$ and $1.0 \mathrm{~g}$ potassium sulfate $(48-52 \%) \mathrm{K}_{2} \mathrm{O}$ before sowing. Prior to NPK application, soil was sample and analyzed (Tab. 1). The soil used had a sandy loamy texure and was characterized by high $\mathrm{pH}$, low organic matter, E.C. and $\mathrm{CaCO}_{3}$. Contents of $\mathrm{Fe}, \mathrm{Mn}$ and $\mathrm{Zn}$ were low. 20 days after sowing, plants were irrigated alternatively with saline water and tap water. Levels of $\mathrm{NaCl}$ used were $0.00,1000$, 2000 and $5000 \mathrm{ppm}$. Irrigation was applied to maintain the water level at $60 \%$ of the field capacity. Two levels $(0.10$ and $0.15 \%)$ of a chelated micronutrient compound containing $\mathrm{Fe}, \mathrm{Mn}$ and $\mathrm{Zn}$ in ratio 1:1:1 and in concentration $2.8 \%: 2.8 \%: 2.8 \%$ was used to correct the nutrient imbalance caused by low mironutrient content and salt stress conditions. Micronutrient treatments were applied on two plant groups. First, before salinity treatments ( 15 days after sowing) and the second one after salinity treatments ( 25 days after sowing). At the flowering stage samples were taken for plant growth measurements and determination of nutrient contents according to Chapman and Pratt (1978).

Tab. 1. Soil physico-chemical characteristics

\begin{tabular}{ccccccccc}
\hline \multicolumn{8}{c}{ Soil Characteristics } \\
\hline Sand \% & Silt \% & Clay \% & Texture & $\mathrm{pH}$ & $\begin{array}{c}\mathrm{EC} \\
\mathrm{dS} / \mathrm{m}\end{array}$ & $\mathrm{CaCO}_{3} \%$ & O.M.\% \\
\hline 70.8 & 6.0 & 23.2 & $\begin{array}{c}\text { Sandy } \\
\text { Loamy }\end{array}$ & 8.08 & 1.44 & 0.04 & 1.36 \\
\hline \multicolumn{7}{c}{\begin{tabular}{c} 
Nutrients Concentration \\
\multicolumn{8}{c}{ Macronutrients } & $(\mathrm{mg} / 100 \mathrm{~g})$
\end{tabular}} & \multicolumn{7}{c}{ Micronutrients $(\mathrm{mg} / \mathrm{kg})$} \\
\hline $\mathrm{P}$ & $\mathrm{K}$ & $\mathrm{Mg}$ & $\mathrm{Ca}$ & $\mathrm{Na}$ & $\mathrm{Fe}$ & $\mathrm{Mn}$ & $\mathrm{Zn}$ & $\mathrm{Cu}$ \\
\hline 4 & 47 & 86 & 371 & 393 & 7.4 & 2.2 & 1.1 & 6.3 \\
\hline
\end{tabular}

\section{Results and discussion}

\section{Effect of salinity on the growth}

Faba bean plants exhibited reduction in growth at the low level of salinity (1000 ppm) $\mathrm{NaCl}$ (Fig. 1 and Tab. 2). Above this level of salinity (2000 and $5000 \mathrm{ppm}$ ) the plants died. The injury effect in response of the high levels of $\mathrm{NaCl}$ attributed to that most legume species are sensitive to salinity (Munns and Tester, 2008). Salts in the soil water may inhibit plant growth for two reasons. First, the presence of salt in the soil solution reduces the ability of the plant to take up water, and this leads to reductions in the growth rate. This is referred to as the osmotic or water deficit effect of salinity. Second, if excessive amounts of salt enter the plant in the transpiration stream there will be injury to cells in the transpirating leaves and this may cause further reductions in photosynthesis processes leading to reduction in growth (Munns et al., 2004 and El-Fouly et al., 2002). The reduction in growth in response of $\mathrm{NaCl}$ may be attributed to the fact that the plants grown under

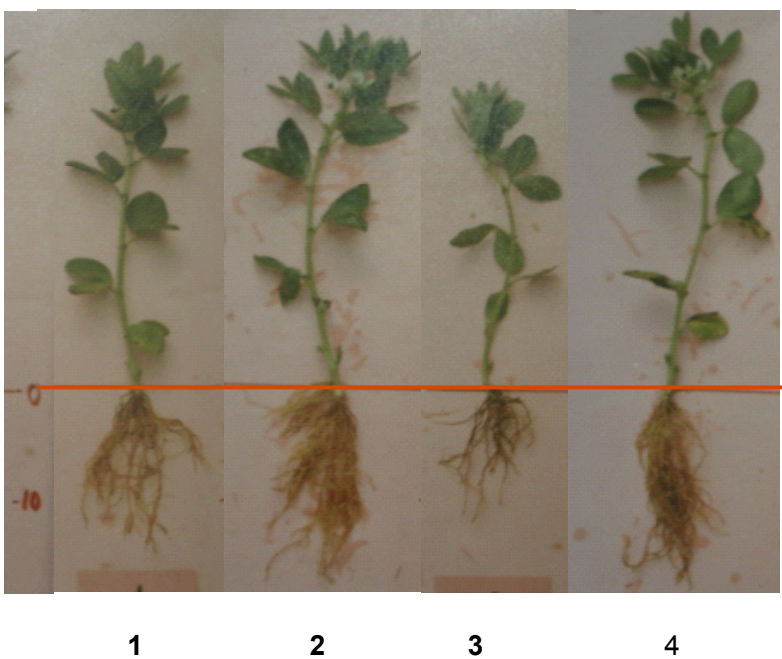

Fig. 1. Effect of micronutrients spraying on the growth of faba bean plant grown under salinity treatment. $1=$ Control (without $\mathrm{NaCl}$ and without micronutrient foliar spray); $2=$ Control + micronutrient foliar spray; $3=1000 \mathrm{ppm} \mathrm{NaCl}$ (without micronutrient foliar spray); $4=1000 \mathrm{ppm} \mathrm{NaCl}+$ micronutrient foliar spray

salt stress conditions alter their stomata resistance due to the increased electronic conductivity in the nutrient solution (Delgado et al., 1993). This reduction has been attributed to salt damage of the photosynthetic tissue,to stomata effects with the consequent restriction of $\mathrm{CO}_{2}$ availability for carboxylation, or as a result of inhibition the enzymes related to $\mathrm{CO}_{2}$ assimilation such as PEP carboxylase and CA activity.

\section{Effect of micronutrient foliar sprays on the growth under salinity conditions}

Salinity adversely affected growth as dry weight. Foliar application of micronutrients had a positive effect on increasing the dry weight of different organs of plants grown under salinity conditions (Fig. 1 and Tab. 2). The highest

Tab. 2. Effect of micronutrient spraying before and after salinity treatments on the dry weight of faba bean plant (g/plant)

\begin{tabular}{ccccc}
\hline NaCl level ppm & Roots & Stems & Leaves & Total plant \\
\hline \multicolumn{5}{c}{ M.N. Before salinity } \\
\hline Control & $0.90 \pm 0.08$ & $1.24 \pm 0.03$ & $1.95 \pm 0.08$ & $4.02 \pm 0.19$ \\
Control $+0.10 \%$ & $1.27 \pm 0.08$ & $1.31 \pm 0.01$ & $2.48 \pm 0.01$ & $5.06 \pm 0.08$ \\
\hline Control $+0.15 \%$ & $1.34 \pm 0.09$ & $1.38 \pm 0.08$ & $2.34 \pm 0.05$ & $5.06 \pm 0.10$ \\
\hline 1000 & $0.34 \pm 0.04$ & $0.66 \pm 0.06$ & $0.75 \pm 0.00$ & $1.75 \pm 0.07$ \\
$1000+0.10 \%$ & $0.70 \pm 0.10$ & $0.96 \pm 0.04$ & $1.54 \pm 0.00$ & $3.20 \pm 0.09$ \\
$1000+0.15 \%$ & $0.65 \pm 0.03$ & $1.03 \pm 0.02$ & $1.58 \pm 0.05$ & $3.26 \pm 0.08$ \\
\hline \multicolumn{5}{c}{ M.N. After salinity } \\
\hline Control & $0.90 \pm 0.08$ & $1.24 \pm 0.03$ & $1.95 \pm 0.08$ & $4.02 \pm 0.19$ \\
\hline Control $+0.10 \%$ & $0.97 \pm 0.01$ & $1.39 \pm 0.08$ & $2.28 \pm 0.17$ & $4.52 \pm 0.20$ \\
\hline Control $+0.15 \%$ & $1.01 \pm 0.01$ & $1.13 \pm 0.06$ & $1.81 \pm 0.00$ & $3.95 \pm 0.07$ \\
\hline 1000 & $0.34 \pm 0.04$ & $0.66 \pm 0.06$ & $0.75 \pm 0.00$ & $1.75 \pm 0.07$ \\
$1000+0.10 \%$ & $0.82 \pm 0.00$ & $1.13 \pm 0.08$ & $2.05 \pm 0.06$ & $4.00 \pm 0.13$ \\
\hline $1000+0.15 \%$ & $0.53 \pm 0.06$ & $1.06 \pm 0.03$ & $1.54 \pm 0.02$ & $3.13 \pm 0.08$ \\
\hline
\end{tabular}

M.N. = Micronutrients 

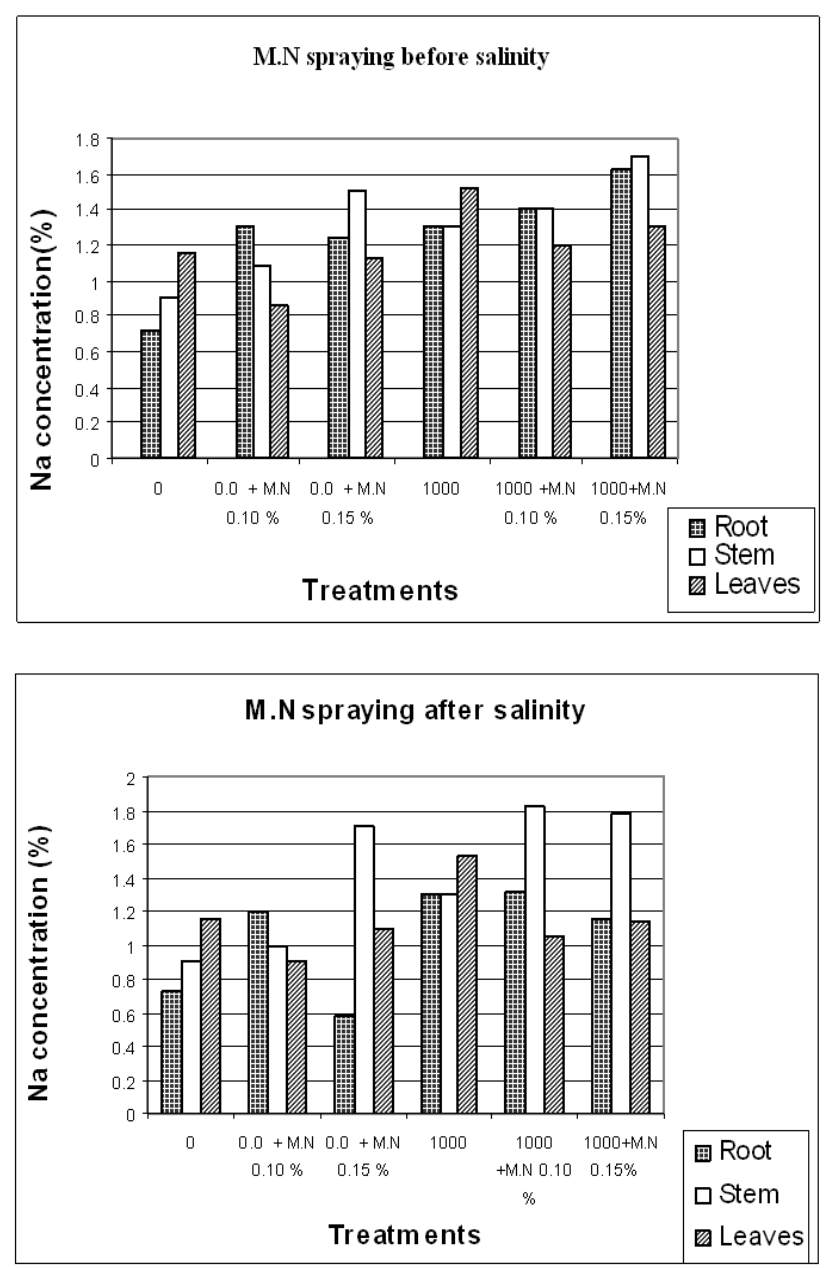

Fig. 2. Effect of spraying micronutrients before and after salinity treatments on $\mathrm{Na}+$ concentration (\%) of faba bean plant; $0=$ without salinity; $1000=1000 \mathrm{ppm} \mathrm{NaCl}$; M.N=micronutrient

increase was observed at $(0.10 \%)$ after salinity treatments. It is intersting to note that spraying micronutrients can improve plant tolerance to salinity by increasing root growth which leads to promote nutrients uptake. The positive effect of $\mathrm{Zn}, \mathrm{Fe}$ and $\mathrm{Mn}$ may be due to their effect as a component of some enzymes or regularory for the others. El-Fouly et al. (2002) found that spraying micronutrients being used to prevent nutritional disorders of crops under salinity coditions. . The positive effect of micronutrient foliar applications can be seen on the performance of growth for roots and shoots also.

\section{Effect of salinity and micronutrients foliar spray on $\mathrm{Na}$} concentration

Sodium concentration of different plant organs of faba bean seedlings was increased in response to the presence of $\mathrm{NaCl}$ in the root growth medium (Fig. 2). Spraying plants with a micronutrient compund after salinity treatment lead to a reduction of $\mathrm{Na}$ concentration on roots and leaves, while it was increasd and accumulated in the stem. Micronutrient foliar applications leads to the decrease of
$\mathrm{Na}^{+}$ions concentrations. Tlis may be contributed to that micronutrients have a control mechanism and/or a regulatory function on the $\mathrm{Na}$ uptake and translocation rate. Micronutrient might be involved in the integriry and function of the bio-membrane of plants (Thalooth et al., 2006)

\section{Effect of salinity on nutrients uptake}

All macronutrients N, P, K, Mg and Ca uptake (Figs. 3, 4) and micronutrients Fe, Mn, $\mathrm{Zn}, \mathrm{Cu}$ uptake (Fig. 5) in different organs of faba bean seedlings negatively relate affected with salinity. Mer et al. (2000) found that $\mathrm{N}$ uptake by barley and wheat plants was reduced as a result of high concentrations of salt in the soil. The reduction of nutrient uptake may be attributed to that high concentration of salts in the soil solution interferes with imbalanced absorption of essential nutritional ions by plants (Lutts et al., 1999; Tester and Davenport, 2003). Grattan and Grieve, 1994 reported that imbalances may result from the effect of salinity on nutrient availability, competitive uptake, transport or partitioning within the plant or may be caused by physiological interactivation of a given nutrient resulting in an increase in the plant's internal requirement for that essential element.

\section{Effect of micronutrient foliar sprays on nutrients uptake} under salinity conditions

Concerning nutrient uptake in different organs of faba bean seedlings, it was found that the nutrients content decreased by increasing salinity. El-Arquan et al. (2002) reported that nutrients uptake $(\mathrm{N}, \mathrm{P}, \mathrm{K})$ were decreased by increasing soil salinity levels. This indicates that exssive content of $\mathrm{Na}^{+}$and $\mathrm{Cl}^{-}$ions in growth media has an inhibitory effect on the uptake and translocation procasses of essential nutrients (Thalooth et al., 2006). Micronutrient foliar sprays showed positive effectes with different degrees on all macro- and micronutrients uptake when sprayed either before or after the salinization treatments (Fig. 3, 4 and 5). Foliar feeding with micronutrients could partially counteract the negative effect of $\mathrm{NaCl}$ on nutrients uptake through improving root growth and prevented the nutritional disorders and concequently caused an increases for the uptake of nutrients by the roots (El-Fouly et al., 2002).

\section{Nutrient ratios}

Concerning the nutrient concentration ratios (Fig. 6) reveals that the ratios were firstely affeced by $\mathrm{NaCl}$ stress. Increasing $\mathrm{NaCl}$ concentration leads to the decrease of $\mathrm{K} /$ $\mathrm{Na}, \mathrm{Mg} / \mathrm{Na}$ ratios. The decrease may be attributed to the increase of $\mathrm{Na}^{+}$ions which diminished the concentration of both $\mathrm{K}^{+}$and $\mathrm{Mg}^{++}$due to antagonistic interaction.

Spraying plants with a micronutrient compund after salinity treatment lead the reduction of $\mathrm{Na}$ concentration of roots and leaves, while it was increased and accumulated in the stems. Consequently, the $\mathrm{K}^{+} / \mathrm{Na}^{+}$and $\mathrm{Mg}^{++} /$ 

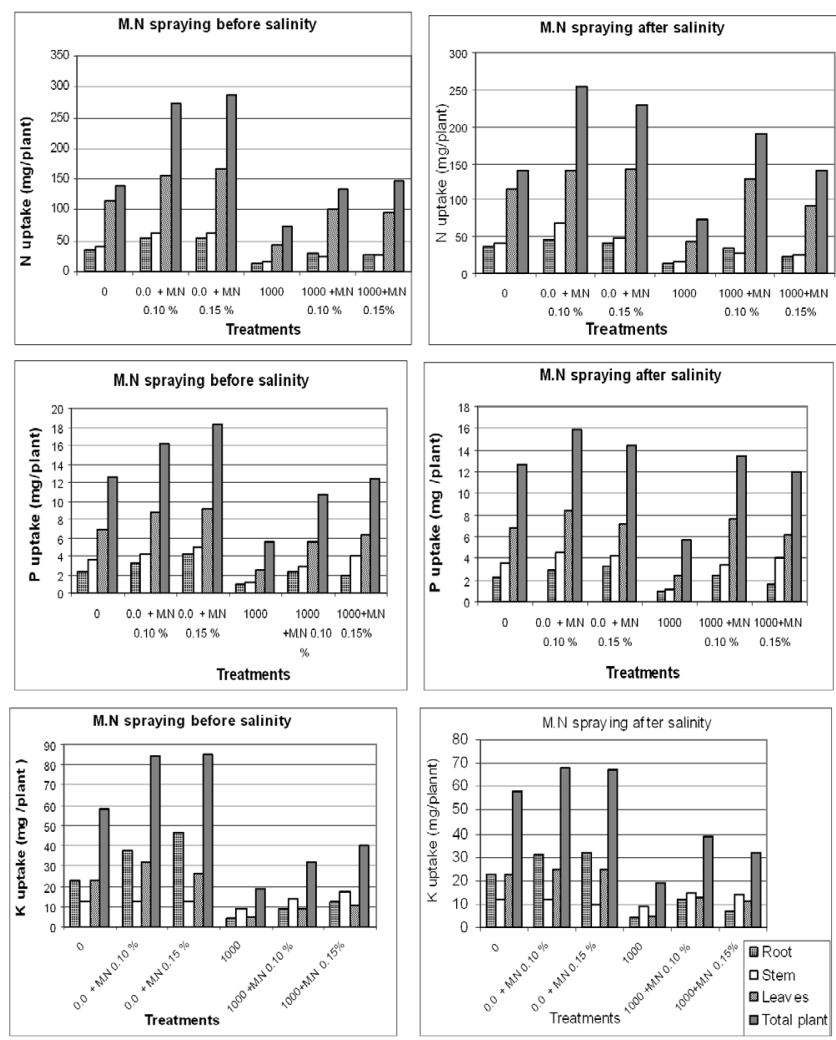

Fig. 3. Effect of micronutrients spraying before and after salinity treatments on $\mathrm{N}, \mathrm{P}, \mathrm{K}$ uptake ( $\mathrm{mg} /$ plant) of faba bean plant; $0=$ without salinity; $1000=1000 \mathrm{ppm} \mathrm{NaCl}$; M.N=micronutrient
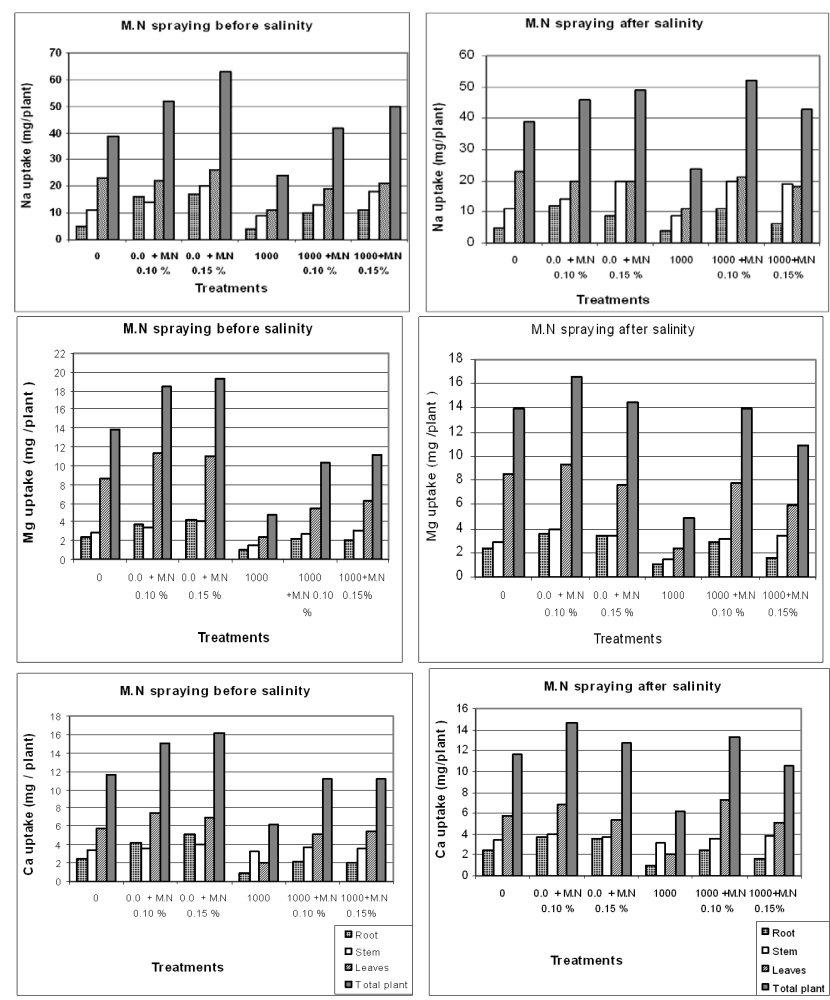

Fig. 4. Effect of micronutrients spraying before and after salinity treatments on $\mathrm{Na}, \mathrm{Mg}$ and Ca uptake (mg/plant) of faba bean plant; $0=$ without salinity; $1000=1000 \mathrm{ppm} \mathrm{NaCl}$; M.N=micronutrient
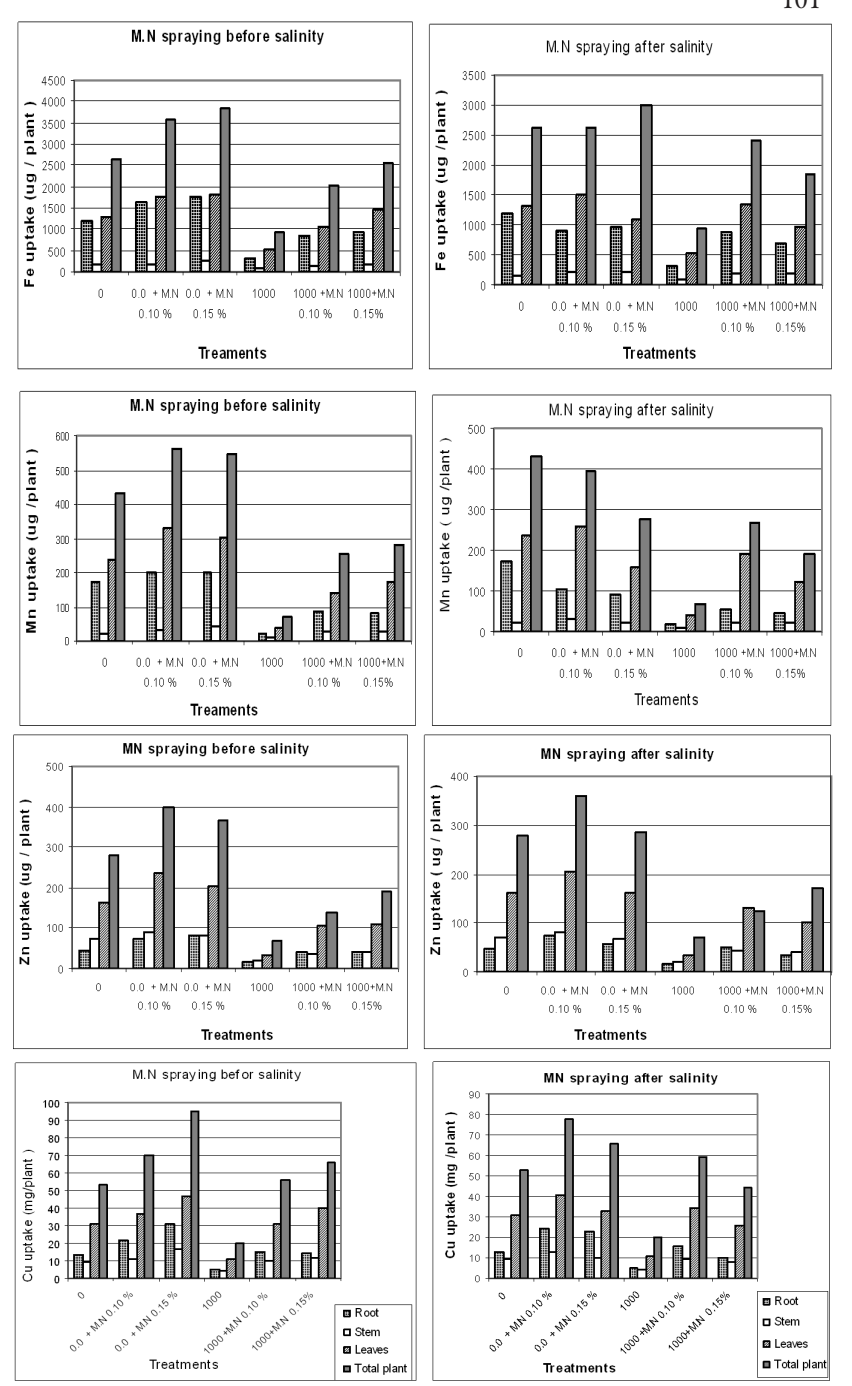

Fig. 5. Effect of micronutrients spraying before and after salinity treatments on $\mathrm{Fe}, \mathrm{Mn}, \mathrm{Zn}$ and $\mathrm{Cu}$ uptake (ug/plant) of faba bean plant; $0=$ without salinity; $1000=1000 \mathrm{ppm} \mathrm{NaCl}$; M.N=micronutrient

$\mathrm{Na}^{+}$ratios in the roots and leaves showed high values, and was reduced in the stem (Fig. 7). This may be attributed to that foliar spray of micronutrients under $\mathrm{NaCl}$ stress, that could increase the capability of root system for selectivity $\mathrm{K}^{+}$and $\mathrm{Mg}^{++}$ions at high concentration of $\mathrm{NaCl}$, which allows the maintenance of the transportation of both ions and the limitation of $\mathrm{Na}^{+}$ion uptake in the shoots (Tattini et al., 1993 and Carvajal et al., 1999). In this respect K/ $\mathrm{Na}$ ratio might be concedered as a tool of plant tolerance to salinity stress.

\section{Conclusions}

From the results obtained, it has been shown that foliar application of micronutrients have a positive effect on growth and nutrients uptake of faba bean plants irrigated with saline water either before or after salinity treatments. 
102
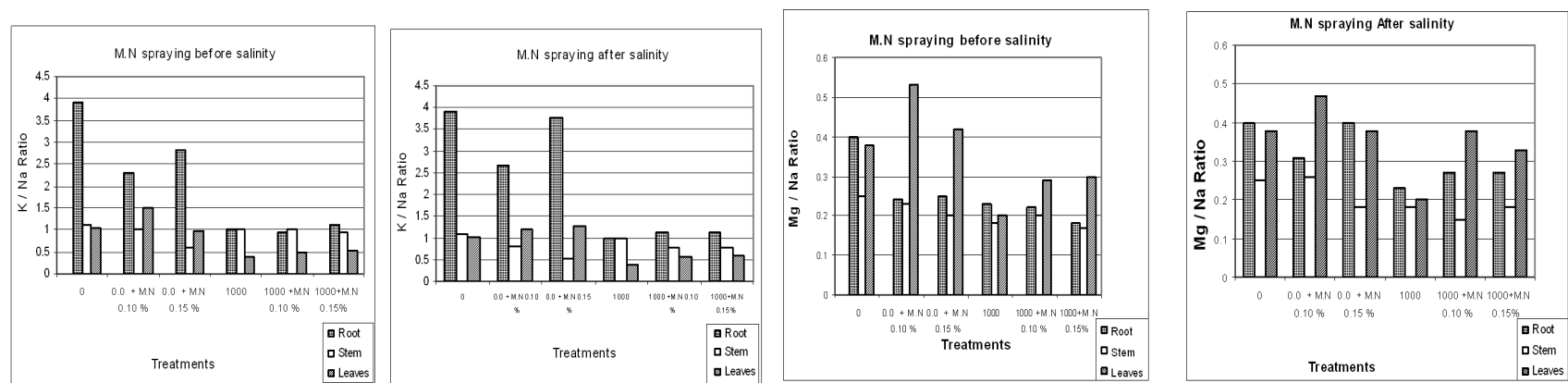

Fig. 6. Effect of micronutrients spraying before and after salinity treatments on $\mathrm{K}+/ \mathrm{Na}+$ and $\mathrm{Mg}++/ \mathrm{Na}+$ concentration ratios of faba bean plant; $0=$ without salinity; $1000=1000 \mathrm{ppm} \mathrm{NaCl} ; \mathrm{M} . \mathrm{N}=$ micronutrient

\section{Acknowledgement}

This work was carried out as a part of the Egypto-German Project "Micronutrient and other Plant Nutrition Problems" implemented by the National Research Centre (NRC) (Coordinator, of. Prof. Dr. M. M. El-Fouly) and the Institute for Plant Nutrition, Technical University, Munich, Germany. The project was supported by the Egyptian Academy of Scientific Research and Technology (ASRT) and the German Fedral Ministry of Technical Cooperation (BMZ) through the German Agency for Technical Cooperation (GTZ).

\section{References}

Carvajal, M., V. Martineze and A. Cerda (1999). Influence of magnesium and salinity on tomato plants growing hydroponics culture. Journal of Plant Nutrition 22:177190.

Chapman, H. D. and P. F. Pratt (1978). Methods of Analysis for soils,plants and waters. Division of Agric. Sci., Univ. California, Berkeley. U.S.A.

Delgado, M. J., J. M. Carrido, F. Ligero and C. Liue (1993). Nitrogen fixation and carbon metabolism by nodules and bacteroids of pea plants under sodium chloride stress. Physiol. Plantarum 89:824.

El-Arquan, M. Y., K. H. El-Hamdi, E. M. Seleem and I. M. ElTantawy (2002). Nutrient uptake of sugar beet as affected by NPK fertilization and soil salinity levels. Egypt J. Soil Sci. 42(4):783-797.

El-Fouly, M. M., Zeinab M. Mobarak and A. Zeinab Salama. Improving tolerance of wheat seedlings to salinity through micronutrients foliar spray. (In press).

El-Fouly, M. M. and Z. A. Salama (1999). Can foliar fertilization increase plant tolerance to salinity? Proc. Dahlia Greidinger Intern. Symp. Nutrient management under salinity and water stress.

El-Fouly, M. M.; Z. M. Mobarak and Z. A. Salama (2002). Micronutrient foliar application increases salt tolerance of tomato seedlings. Proc. Symp. Techniques to Control Salination for Horticultural Productivity. Akosy U. et al., Eds. Acta Hort. 573:377-385.
El-Fouly, M. M., E. A. A. Abou El-Nour and A. A. AbdelMaguid (2004). Counteracting effect of foliar application of macronutrients on spinach beet (Beta vulgaris var. cycla) grown under NaCl-salinity stress. Agric. Cairo Univ. 55:587602.

Gama, P. B. S., S. Inanaga, K. Tanaka and R. Nokazawa (2007). Physiological response of common bean (Phaseolus valgaris L.) seedlings to salinity stress. African Journal of Biotechnology 6 (2):79-88.

Grattan, S. P. and C. M. Grieve (1994). Mieral nutrient acquisition response by plants grown in saline environments, pp. 203-226. In: Pessarakli, M. (Eds.). Handbook of Plant and Crop Stress. Marcel Dekker. New York.

Hasegawa, P., R. A. Bressan, J. K. Zhu and H. J. Bohnert(2000). Plant cellular and molecular responses to high salinity.Annu. Rev.Plant Physiol.Plant Mol.Biol. 51:463-499.

Khan, M. A. and N. C. Duke (2001). Halophytes-A resource for the future. Wetland Ecology and Management 6:455-456.

Lutts, S., J. M. Kinet and J. Bouharmont. Improvement of rice callus regeneration in the presence of $\mathrm{NaCl}$. Plant, Cell, Tissue and Organ Culture 57(1):3-11.

Mer, R. K., P. K. Pajith, D. M. Pandya, A. N. Pandey (2000). Effect of salts on germination of seeds and growth of young plants of Hordeum valgare, Triticum aestivum, and Brassica juncea. J. Agro. Crop Sci. 185(4):209-217.

Munns, R., S. S. Goyal, J. B. Passioura (2004). Salinity and its migitation. Website. Blum A. (Ed). (http://www.plantstress. com/Articles/index.asp).

Munns, R. and M. Tester (2008). Mechanisms of salinity tolerance. Ann. Rev. Plant Biol. 59:651-681.

Thalooth, A. T., M. M. Tawfik and H. Mohamed Mogda (2006). A comparative study on the effect of foliar application of zinc, potassium and magnesium on growth under water stress conditions. World J. Agric. Sci. 2:37-46.

Tattini, M., P. Bertoni and S. Caselli (1993). Genotypes responses of olive plants to sodium chloride. J. Plant Nut. 15:1467-1485.

Tester, M. and R. Davenport (2003). Na tolerance and Na transport in higher plants. Annals of Botany. 91:503-527. 